\title{
1 \\ CLAIMING LAND FOR THE BRITISH EMPIRE
}

\section{Captain Moresby and the Binandere (1873-74)}

A 'basilisk', according to Wikipedia, is a legendary reptile mentioned in European bestiaries and reputed to be 'King of Serpents'. It is said to have the power to cause death with a single glance. Basilisk was also the name of a British Navy paddlewheel steamer, carrying sails, of 1,031 tons. It was captained by John Moresby and was used to survey the coastline of southeastern New Guinea island, beginning in 1873 and returning to complete a second phase of mapping in 1874 (Moresby 1876). Such a ship's name might intimidate some English-speakers, but not the Binandere people on the then little-known part of the north-eastern coast who had their own language and life experiences. They may, nevertheless, have been impressed both by the great size of HMS Basilisk and by the strangeness of its white-skinned crew of 178 officers and men who had appeared on their coastline. This 'first contact' between the colonising British Empire and the indigenous Binandere, also spelt Binandele, and the many encounters that followed elsewhere, were not in the least peaceful. Further, the invaders had the advantage of rifle power. 


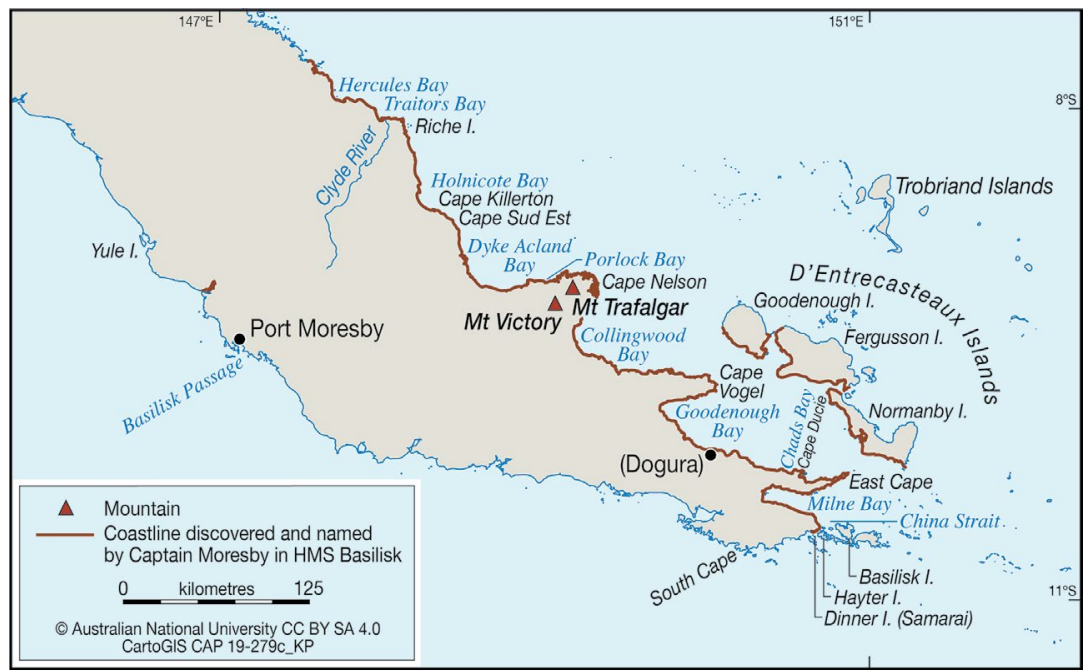

Figure 1.1. Coastal surveys by Captain John Moresby

The coastlines of south-eastern New Guinea surveyed by John Moresby in 1873-74 are shown in this map together with a selection of place names taken from the chart published by Moresby (1876; see also Whittaker et al. 1975, plate 44). The Basilisk survey started in the west on the south coast, near where Captain Moresby gave family names to both the main harbour of Port Moresby and to an inner one, Fairfax Harbour. The name of the Basilisk was given to both a passage through fringing reefs and islands into Fairfax Harbour and to an island on China Strait in the extreme south-east. Headquarters of the Anglican mission at Dogura were later built on Goodenough Bay. The mountain known later as Mount Lamington is 40 kilometres south-west of Cape Killerton but was not recorded by Moresby.

In 1874, Captain Moresby named two bays along the north-eastern coast of south-east New Guinea that border the mainly flat country occupied by the Orokaiva. The first one he called 'Dyke Acland, after my revered friend the late Sir Thomas Dyke Acland, [Baronet]' (Moresby 1876, 272). The second bay, to the north-west, was named Holnicote Bay after an aristocratic estate in Somerset, England, that was once owned by Sir Thomas. Captain Moresby's naval and English loyalties had come to the fore a few days earlier in the coastal survey to the east when he applied the name 'Cape Nelson' to a 'lofty promontory' (269). Two conspicuous and 'picturesque' peaks on the promontory, or peninsula, were called 'Victory' and 'Trafalgar', and the bay to the east of them was named after Lord Collingwood (Figure 1.1). All of these names were proud reminders of the British victory over the Franco-Spanish fleet at the Battle of Trafalgar in 1805 . 
Moresby did not recognise Mount Victory as an active volcano, or the volcanic nature of either Mount Victory or Mount Trafalgar, but he did say that the mountains 'descend to the sea in open grassy and wooded slopes, which have all the appearance of English parkland' (Moresby 1876, 271) —a hint, perhaps, of some homesickness. England and the Empire were in any case predominant. Moresby also gave no indication of any volcanoes existing inland from Dyke Acland Bay.

The French voyager Bruny d'Entrecasteaux had sailed off the same north-eastern coast in 1793. He encountered and named the D'Entrecasteaux Islands but went north to the Trobriand Islands (Figure 1.1) and then northwest, staying well offshore from the mainland (Duyker and Duyker 2001). No detailed coastal mapping was undertaken by d'Entrecasteaux, and two coastal points located and named by him-Cape Sud-East and Riche Island-were later discovered by Captain Moresby to have coordinates that plotted inland. Moresby, however, kept the names of these points as a courtesy to d'Entrecasteaux. This coastline is shown blank on the first published map of Australia by Freycinet in 1811 (Figure 1.2).

Captain Moresby was further up the north-east coast on 8 May 1874 when he encountered the mouth of a large river, which he called rather patriotically 'the Clyde', but which a few years later was given its local name of Mambare or Mamba. It is the largest river in this belt of coastal country. The captain here also came across 'a beautiful bay running up to a sandy beach, fringed with groves of a kind of fir tree, admirably adapted for firewood, of which we were now much in need' (Moresby 1876, 275). They anchored, 'rather glad that no villages were at hand' (275).

Wood collection by crew members of the Basilisk had begun the next morning when 'a large number of armed natives' (276) landed from canoes and were seen from the Basilisk stalking three officers on the beach. Moresby and Sub-Lieutenant Shortland immediately took rifles to the shore in a dinghy. The concealed warriors broke cover, an advancing frontline armed with spears followed by a supporting line of men carrying clubs. Moresby 'fired with a snap-shot at the leading savage' (276; Figure 1.3). He missed the man but hit his shield, and the noise and effect of the fracas was enough to send the alarmed attackers into retreat. The Basilisk sailed away on the following morning, 10 May, now carrying about 40 tons of the acquired wood. The name 'Traitors' Bay' was given to this first-contact location by the British voyagers. Equally, however, the Binandere would have been justified in calling this place of attack Woodtheft Bay or even Invasion Bay. 


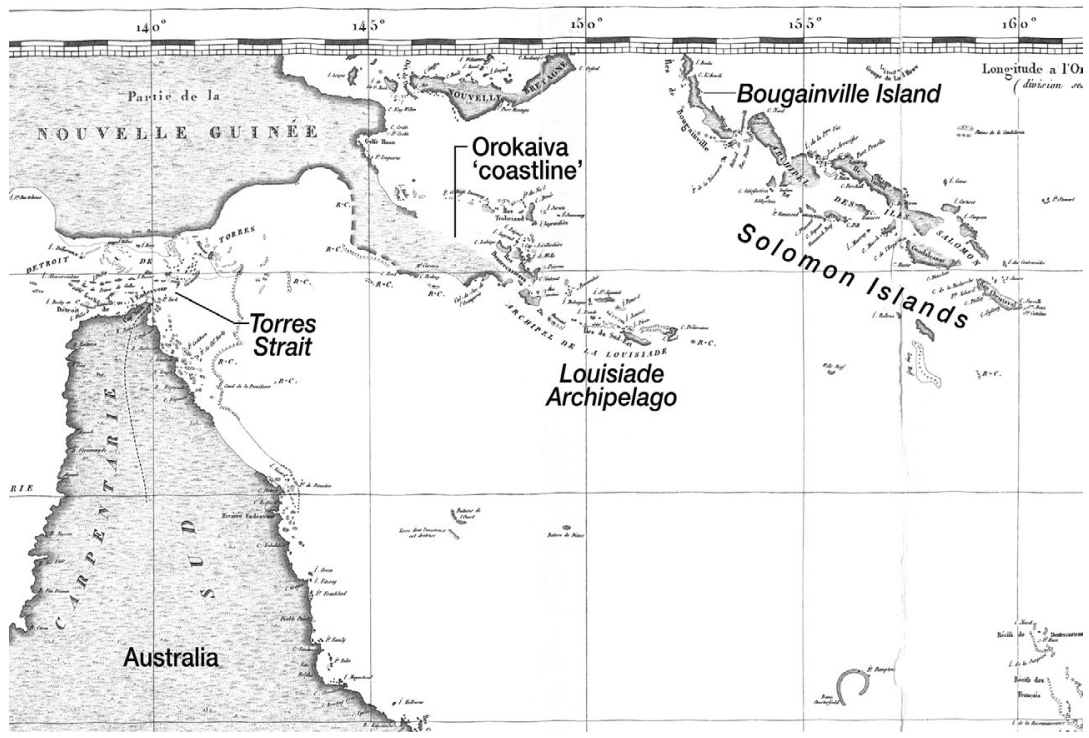

\section{Figure 1.2. North-eastern part of Freycinet map of New Holland}

This is an annotated detail from the 'General Map of New Holland', one of 14 charts from the Baudin expedition of 1800-04 (Freycinet 1811). The whole of the coastline of the Australian continent had been mapped by this time, as well as the islands of Torres Strait, the Louisiade Archipelago, Bougainville Island and Solomon Islands, but not the coastline along the north-east coast of south-eastern Papua, which is shown blank. This detail was provided courtesy of the National Library of Australia, Canberra.

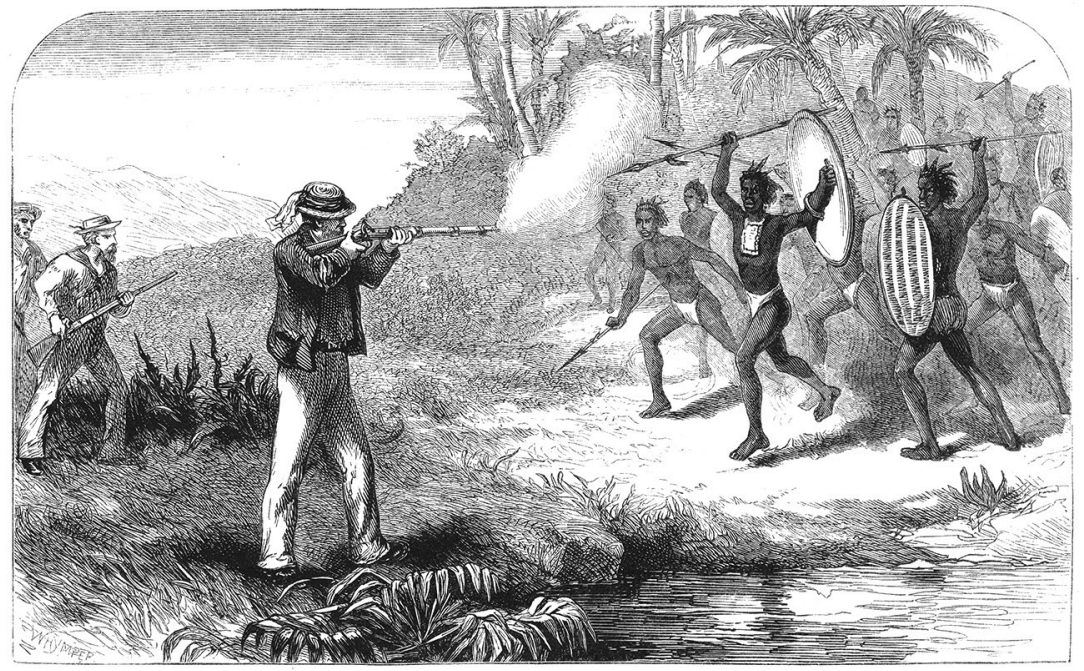

\section{Figure 1.3. Shooting at Traitors Bay}

The published caption to this illustration reads 'Attack of Natives, Traitors' Bay, North-East New Guinea' (Moresby 1876, between 276 and 277). This digital image was provided courtesy of the National Library of Australia, Canberra. 
Moresby's coastline survey of south-eastern New Guinea was regarded as a success by the British, given that this part of New Guinea's shoreline had long been neglected because of its dangerous reefs, shoals, currents and strong south-east trade winds. Further, navigating through the numerous islands extending eastwards from the tip of New Guinea had been risky. Ships trading between Australia and China avoided the area even though this entailed a lengthening of the voyages. Moresby's discovery of China Strait, however, just off the eastern tip of New Guinea, alleviated this necessity. In celebration of his significant discovery, Moresby had raised the Union Jack on 24 April 1873 on Hayter Island-named after the senior lieutenant on the Basilisk - and made a declaration of formal possession by Britain 'in the name and on behalf of her most gracious Majesty Queen Victoria' (Moresby 1876, 208). He 'discovered' Milne Bay and named Dinner Island after a meal he had there, which would later become known more famously as Samarai. The coastline mapping by the Basilisk officers, led by Lieutenant L.S. Dawson in 1874, would be used on the British Admiralty's navigation chart that was first published in 1886 (Dawson and Officers 1886) and reproduced in many subsequent editions.

Moresby was not the first British naval commander to sail in the coastal waters of south-eastern New Guinea. HMS Rattlesnake, under the command of Captain Owen Stanley, accompanied by the Bramble, had sailed westwards along the south coast of the island in 1849. Stanley noted that mountains behind the coast to the north 'seemed piled one above the other to an enormous height ... [and were] intersected by tremendous gorges' (quoted in Goodman 2005, 244-45). The mountain axis seemed to follow the coast and appeared like a giant backbone to the island. The mountains eventually, and indeed inevitably, inherited the name 'Owen Stanley Range', although Stanley himself was fearful of disembarking from the Rattlesnake and exploring any further because he imagined that 'the natives are warlike, very numerous, well armed and very treacherous' (Goodman 2005, 245). This magnificent mountain range can be seen also from the north-east coast, forming on clear days a spectacular backdrop to the mainly flat country occupied by the Papuans. Mount Victoria is a nearby high point in the Owen Stanley Range that reaches over 4,000 metres above sea level. No inland volcanoes were sighted from the Rattlesnake. 
Powers in Europe other than Britain were, by the 1870s, taking their own imperialistic interest in New Guinea island (Gordon 1951; Whittaker et al. 1975). The Dutch had already claimed the western half of New Guinea, west of $141^{\circ} \mathrm{E}$, and the navies of Germany, Russia and France were becoming, or had already become, familiar with New Guinea's surrounding waters and smaller islands. The self-governing colonies of Australia accordingly were rather sensitive to, if not fearful of, the potential threat from these foreigners - especially from the Germans-and urged creation of a British New Guinea as part of the Empire. The tropical islands were being regarded by Australian colonists as a strategic bulwark or 'shield' for Australia's defence from potential invaders - and unwanted migrants-further north in Asia (e.g. Hunt 2017). There was also interest within the self-governing colonies of Australia in the British settlement and development of the agricultural potential and mineral resources of New Guinea, particularly its gold. The British Government in London in the late 1870s, however, was not yet in favour of accepting eastern New Guinea as a new colony of the Empire, and it resisted these pressures from the Australian colonies_ and from the Christian churches too.

\section{Tsunami from the West (1873-1900)}

\section{Arrival of the colonists}

British imperialism had emerged from the experience of centuries of written history, Christianity, gunpowder-fuelled militarism, the Scientific Revolution, the Enlightenment and the Industrial Revolution-including development of wood-fuelled paddle-steamers. A few Europeans arrived with a modicum of sensitivity and insight, but the great remainder included, according to one list, 'immoral settlers, misinformed missionaries, ruthless officials, paternalistic administrators, racist expatriates, and self-interested capitalists' (Trompf 1987b, 6). All of these influences had, until 1874, bypassed the people in the isolated north-eastern part of south-east New Guinea. The Christian-influenced, British imperialists, however, would soon attempt to dominate the people on this north-eastern coast and to change those aspects of their behaviour judged to be 'uncivilised'.

European white men caused breakdowns of traditional life in Melanesia and in Australia. A modern-day Melanesian philosopher, Bernard Narakobi, likened their arrival to invasion by a huge 'tidal wave' or tsunami (Narakobi 1980, 8). This wave of colonisation and Christianisation came 
forcefully and destructively, forever changing established cultures and depositing 'much rubbish' ( 8 , see also quotation at the beginning of Part 1 of this book). However, as Narakobi observed, the Western tidal wave also triggered changes of thought among the Melanesians and a desire for a better future.

Black peoples had arrived in New Guinea island much earlier than the Europeans, having made their Pleistocene sea crossings from SouthEast Asia to the combined Australia-New Guinea, or Sahul, continent by 40-50,000 years ago (Pawley et al. 2005; Summerhayes et al. 2010, 2017; Golson et al. 2017). Early arrival of black peoples to the New Guinea region is thought to have started in the western coastal areas of the island, but eastward migrations eventually led to occupation of isolated valleys in mountainous terrain and along scattered island chains. This was well before the melting of ice from the Ice Age caused rising sea levels and the creation of different Australian and New Guinea landmasses, separated by channels such as the one now known as Torres Strait. How long people took to reach the eastern 'tail' of New Guinea is unclear. Postglacial sea level rises may have flooded archaeological evidence for possible settlements on or near shorelines—such as along the north-east coast of Papua surveyed by Captain Moresby.

Australian Aboriginal people, in general, formed mobile hunter-gatherer societies, moving through large tracts of land that were not conducive to agriculture. The Melanesians of New Guinea, in contrast, typically combined their foraging and hunting with gardening and animal husbandry. They could achieve greater population densities this way because of the availability of foods such as yams and sweet potatoes, but those higher densities in some circumstances placed them at-risk in settled areas that were geophysically hazardous. Agriculture in the valleys of the New Guinea Highlands dates back to about 10,000 years (Summerhayes et al. 2010, 2017; Golson et al. 2017).

The Melanesians also generated an extraordinary diversity of numerous non-Christian religions, languages, dialects and discrete cultures (Pawley et al. 2005; Pawley and Hammarström 2018). Their religions had their own theologies, prophets, rituals and ceremonies together with a capacity to develop new cults or movements when the need arose, such as when white men arrived with their new ideas and wealth in the form of 'cargo' (Trompf 1977, 1987a, 1987b). The languages of New Guinea island comprise a 'Papuan' or Trans-New Guinea phylum consisting of at least 
347 languages according to one linguist (Ross 2005), and there are many others for which the data are too slender to make possible assignments to the phylum.

Christian missions in the 1870 s were committing to vigorous proselytising among the dark peoples of 'heathen' New Guinea following the evangelical revivals of the seventeenth and eighteenth centuries in Britain (Chignell 1913; Tomlin 1951; Tomkins and Hughes 1969; Wetherell 1977, 1996; Langmore 1974, 1989). The London Missionary Society (LMS), in particular, was already interested in the establishment of a Protestant mission base on a protected natural harbour on the southern coast of New Guinea. The main part of this harbour had been called Port Moresby in 1873 by the captain of the Basilisk, and its inner part received the name Fairfax Harbour after the captain's father, Admiral Sir Fairfax Moresby (e.g. Stuart 1970). The first European LMS mission station was established on the shores of the harbour when Reverend and Mrs W.G. Lawes arrived in the following year, 1874. Lawes and, later, his exuberant and unconventional colleague James Chalmers were dedicated to the establishment and development of LMS mission stations eastwards along the south coast of New Guinea to the eastern end, where the highly influential Kwato Mission was established (Langmore 1974; Wetherell 1996).

The first Christian missionaries in Papua were not white men but brown Pacific Islanders. They played an essential role at both Port Moresby and at Kwato as an advanced guard for their later European colleagues. The Pacific Islanders at Port Moresby were originally from the Melanesian Loyalty Group. They had settled at Hanuabada village before the arrival of the Lawes, and previously had been missionaries in the nearby Torres Strait Islands. The approach of the Pacific Islanders to evangelisation seems to have been somewhat different to that of the Europeans who preached from the gospels. The white men taught about a forgiving god of love, as witnessed by the presence on Earth of Jesus Christ, his own son, who was reputed, whether in truth or myth, to be a mild if not meek person but who nevertheless whipped the moneylenders in the temple at Jerusalem.

The Loyalty Island missionaries, in contrast, plus others from Polynesian islands, appear to have preferred the tougher stories of Jehovah and the Old Testament conception of a god of wrath. Perhaps they recognised, too, that this was a more effective way of engaging their warrior-like Papuan 
brothers in the process of Christian conversion. John Bruce, magistrate and schoolteacher in the Torres Strait Islands, said after two earth tremors had been felt on Murray Island in 1899, that the local islanders had concluded 'God had been very angry'. Bruce wrote that:

The South Sea teachers know the kind of God to depict to the native far better than the white missionary does; his God of Love is beyond their comprehension. They look as if they believed in Him, but converse with them, and you find the God of Wrath is their ideal of what God is. (Haddon 1901, 80)

This is not the only time that the 'wrath of god' is used as an explanation for the impact of geophysical hazards, including volcanic eruptions, nor the last time that inaccurate interpretations would be made by Europeans about the true nature of indigenous black religions (e.g. Trompf 1987a, 2006).

A Torres Strait magistrate, Henry Chester, raised the Union Jack at Port Moresby on 4 April 1883, thus repeating the ceremony of colonial intent undertaken by Captain Moresby 10 years earlier on the tiny offshore Hayter Island. This was a timely prelude to 1884 when the whole of New Guinea island, and adjacent islands, were partitioned by the imperial powers in Europe. Britain established a Protectorate over south-eastern New Guinea, which was administered initially by a special commissioner. Germany took north-eastern New Guinea, and the Dutch kept the western half of the island. The southern boundary of German New Guinea at latitude $8^{\circ} \mathrm{S}$ marks roughly the northwestern limit of the people known as the Orokaiva who thus came under British control. The main administrative and trading centre for the British would be Port Moresby on the south coast, meaning that reaching the isolated north-eastern coast by land from Port Moresby was impractical owing to the barrier of the towering Owen Stanley Range. Therefore, government and administrative officials, missionaries, miners, traders, curious travellers and Australian recruiters requiring native labour for the Queensland sugar plantations used coastal vessels to sail eastwards, through China Strait, and then westwards round to the north-eastern coast. These vessels included the familiar SS Merrie England, a screw steamer boat of 260 tons gross, which was used frequently by the administrator, his officers and visiting dignitaries. 
Another significant year for the Empire and New Guinea was 1888. British New Guinea in that year was declared a full possession of the Crown-not merely a Protectorate. Sir William MacGregor became its first administrator and, later, lieutenant governor (Joyce 1971). MacGregor was an energetic explorer of the country under his control and a determined and resolute leader. He also imposed an organisational and management structure on the colony during his 10 years in the role of administrator, during which he was accountable to the British-appointed governor of Queensland based in Brisbane. A series of British and, later, Australian colonial administrators held a general belief in a policy of economic and social development of their indigenous subordinates, if not inferiors, but they had no patience with cannibalism, sorcery, headhunting, skull collection, infanticide, inter-tribal warfare, anti-white cargo cults, polygamy, traditional dancing leading to too much fornication and debauchery, and certainly no acceptance of physical attacks on whitesespecially fatal ones.

\section{Meeting the Orokaiva}

A dominant geographical feature of the belt of country along the north-eastern coast of New Guinea is the so-called 'northern rivers' area where four main rivers in the north-west drain off the Owen Stanley Range. These meander in their lower courses north-eastwards towards the sea through an extensive swampy basin that runs parallel to the coast, and that easily becomes flooded especially during monsoonal times. The Mambare and Kumusi are the two largest of the four rivers, but the smaller Gira and Opi were no less important. All of them were used by the colonists as highways of access to the interior and to the peoples who live there.

William McGregor visited the coast near the mouth of the Mambare in 1890 in the Merrie England, near where John Moresby had landed 16 years earlier. MacGregor was also in 1894 the first foreigner to ascend the Gira and Opi, and to take a steam launch as far as he could up the Mambare and Kumusi rivers. MacGregor encountered river-shore villagers who were prepared to trade, but he was also confronted by armed parties whose behaviour may have been welcoming, propitiating, intimidating or perhaps simply a 'testing' of the unknown - he could not decide (MacGregor 1890; Williams 1930; Joyce 1971; Nelson 1976). The Orokaiva in any case soon gained a reputation, in the minds of the 
colonists, as exceptionally savage warriors known for their fearsome raids on traditional enemies and for having little compunction about attacking, retaliating and killing the invading whites.

Village people on the Mambare shouted out 'orokaiva!', which the foreigners thought was some sort of greeting, or perhaps a password or statement of presence, for those who came in peace. The word was later used by white travellers throughout the district and was soon adopted by them for all of the local people along this north-eastern belt of south-eastern New Guinea. 'Orokaiva' in that context actually refers to a loosely related group of peoples sharing a broad yet common culture but having different languages and dialects. The people encountered by both Moresby and MacGregor along the Mambare were in fact the Binandere, a name subsequently used by academic linguists for all of the languages of Orokaiva country (e.g. McElhanon and Voorhoeve 1970; Pawley 2005). The Binandere family of languages belongs to the ancient 'Papuan', or non-Austronesian, family of languages signifying, but not proving, that the Orokaiva, or at least their predecessors, may have occupied this country for many thousands of years, possibly even back into the Pleistocene.

British New Guinea was split into geographical 'divisions', each of which was administered by a resident magistrate responsible only to the administrator. The resident magistrate was the representative of British law and its enforcement, as well as the head of all executive and administrative affairs in his division, and much else besides. The early resident magistrates tended to have exuberant, independent and adventurous personalities, and were provided de facto by the administration with a considerable amount of local power, especially in difficult postings that were distant from Port Moresby. They created uniformed constabularies of armed native police composed of selected men, some from parts of the colony that were distant from divisional headquarters. Resident magistrates also needed to acquire some knowledge of the nature of the strange people and cultures they were administrating and attempting to change. This proved to be a challenge for some of them, and a test of patience too. Some of the resident magistrates of a more racist persuasion were found to be rather free in their use of firearms in controlling and killing the fractious and aggressive Orokaiva. 
MacGregor observed from Dyke Acland Bay in late 1893 the inland landscape just west of the newly named 'Hydrographers Range' in the Northern Division. It was flat and swampy country:

Bounded by an extension of the [range], which extends away into the interior in a series of nearly detached hills, from a few hundred to two or three thousand feet high. These are forest-clad, but many clearings have been made, apparently for cultivation purposes. (MacGregor 1893, 2)

This description of gardens on higher ground immediately west of the Hydrographers Range probably refers to cultivation by the mountain Sangara group of Orokaiva, in which case the ground would have been the northern slopes of what later would be called Mount Lamingtonand much later identified as a volcano.

\section{Gold prospecting}

Australian gold prospectors in the 1870s and 1880s had had some success south of the Owen Stanley Ranges and in the islands east of the south-eastern end of New Guinea, and they turned their attention to the northern side of the range after MacGregor's trips up the northern rivers in 1894 when gold 'colours' were found in the Mambare (MacGregor 1894). George Clarke and others from the Cairns Prospecting Association reached the Mambare in July 1895, but the Binandere people were not welcoming and Clarke was killed by one of them. This was the start of years of deadly clashes in the northern rivers area between Orokaiva warriors and the invading prospectors and administration officers (Nelson 1976; Wetherell 1977). Successful prospecting for the alluvial gold did not come easily: 'There's a lot of gold in New Guinea, but there's a lot of New Guinea mixed with it', said the prospectors (Nelson 1976, 120).

The administrator was on the north coast with the Merrie England in 1895 when he heard of Clarke's killing. He headed for the Mambare River, assessed the unstable situation there, and evacuated the remaining miners. The administration could not, and did not, retreat in such circumstances, and the Merrie England was sent on for police reinforcements. MacGregor first, however, accompanied by his government secretary, John Greenand by some of the gold prospectors-took the opportunity of exploring part of the Musa River area while waiting for the return of the reinforcements. The Musa drains into the south-eastern shore of Dyke Acland Bay near Porloch Bay, about 150 kilometres south-east of the mouth of the Mambere (Figure 1.1; see also Figure 2.2). 
The administration party was in a launch on the Musa River travelling back downstream in September when they encountered a raid by the Orokaiva-a powerful, 'almost spectral' flotilla or 'armada' of canoes moving fast and impressively upstream in the dawn light (MacGregor 1895, 27). There were between 30 and 40 large canoes, each full of warriors-about 400 in total-and all decked out in war gear. Each of two men in the largest canoe in the centre, who evidently were leaders, were covered with paint and plumes and they held banners made from white feathers fixed on to spears.

The flotilla made its way silently and purposefully past the MacGregor party, ignoring the foreigners, although one warrior did call out 'orokaiva' 'in a low hollow tone' (MacGregor 1895, 27). MacGregor collected additional police from the Merrie England, which by now had anchored in Dyke Acland Bay, and the next day he went back up the Musa with his armed reinforcements. There they saw gardens devastated by the raiders, and abandoned canoes with roasted human legs, arms, ribs, heads, backbones and so on, some partly eaten, plus the body of young girl, her skull smashed and her body prepared for cooking. There were also neatly made-up parcels and packets of human flesh, and prepared coils of human intestines. Swift and deadly retribution for the warriors of the flotilla was judged by the administrator to be appropriate and fatal shootings followed. John Green 'felt no mercy as he fired', remembering the body of the young girl and her smashed skull (Nelson 1976, 96).

MacGregor next appointed John Green to be his government agent on the Mambare to protect the gold prospectors, and to bring the north-western Orokaiva, the Binandere people, under government control. The Binandere had by this time, in late 1895 and after George Clarke's killing in July, established a reputation as indiscriminate and fierce killers, so Green's task was certainly a challenging one. Green suffered fatal consequences himself at the Tamata Government Station on the Mambare on 14 January 1897 when he and eight others in his administration group were killed by the Binandere. A retributive, dominating and effective response was provided by MacGregor against the perpetrators.

The prospectors persevered even in these circumstances and, by 1890 , had been rewarded by significant gold finds in the Yodda Valley, an upper tributary of the Mambare (Nelson 1976). A goldfield was declared, attracting further interest from those new alluvial miners who were prepared to put up with the Orokaiva, the considerable supply costs 
of being so far inland, and poor food and tropical diseases-malaria, dysentery, dengue fever and blood poisoning through tropical ulcers and untreated wounds.

\section{Anglican Missionisation (1891-98)}

The trident of British imperialism consisted of administration officials supported by armouries, evangelistic missionaries carrying the gospels and private enterprise requiring profitable investment. All three in British New Guinea, as elsewhere, depended on reaching an acceptable and pragmatic equilibrium by means of political process. The Christian missions and missionaries themselves, however, had different approaches to evangelisation.

MacGregor was a crofter's son brought up in Scotland where he was influenced by the Presbyterian Church of Scotland. MacGregor in British New Guinea, however, was more concerned about establishing effective alliances with all of the Christian missions whether Protestant or Roman Catholic. He was a strong supporter of missionisation and, indeed, was obliged to be so in practical terms because missionary work provided not only, hopefully, a pacifying role through the spiritual teachings deriving from a god of love, but also education-reading, writing and arithmeticthrough mission schools, as well as improved physical health through nursing services and hospitals. MacGregor had trained as a medical doctor, so he brought to the task of administrator a scientific approach to his observations and recording.

The local impact of Christian teaching was already evident early in MacGregor's rule when the administrator and his officers swept through a score of villages on the north-eastern coast of Papua, north of Milne Bay, in late 1888. This was a response aimed at capturing offenders following a killing of a European trader at Chads Bay near Cape Ducie. MacGregor asked Komodoa, the headman at Polotona village, if he had been involved in the attack, and he received the reply: 'No! too much fear God' (Wetherell 1977, 29). Such a view of Christianity may well have originated from the Pacific Island missionaries on Milne Bay and is much the same kind of 'wrath of god' reaction recorded later by John Bruce on Murray Island after earth tremors were felt there. The kind of commonsense pragmatism displayed by Komodoa at Chad's Bay, however, had not yet emerged from the un-evangelised Orokaiva further to the north-west. 
The Roman Catholics in 1885 had already established the Sacred Heart Mission on Yule Island north-west of Port Moresby, later extending their influence among the people on the nearby coast and mainland interior. Similarly, the LMS Kwaito Mission was well established by 1890 on the shores of China Strait and Milne Bay. Three other church missions by 1890 had also reached an agreement, facilitated by MacGregor, that separate 'spheres of influence' should be defined for south-eastern New Guinea (Langmore 1974, 148, note 14). The Anglicans would proselytise in a belt of paganism on the isolated north-eastern coast, extending from Cape Ducie in the east—named by Captain Moresby after the Earl of Ducieto the border with German New Guinea, or the 'Old Protectorate', in the north-west. Their territory, therefore, included all of Orokaiva country. The Wesleyan Methodists would take the D'Entrecasteaux Islands plus a narrow strip east of Cape Ducie, and LMS influence would continue to extend from Kwaito, westwards along the south coast of New Guinea towards the border with Dutch New Guinea, excluding Sacred Heart territory.

The founding fathers of Anglicanism in south-eastern New Guinea were Reverend Albert Alexander Maclaren and Reverend Copland King (Chignell 1913; Tomlin 1951; Tomkins and Hughes 1969; Langmore 1989). They decided in 1891 to establish their mission headquarters at Dogura, Bartle Bay, on a remote stretch of coastline west of Cape Ducie (Figure 1.1). The mission was built on a terrace above the shoreline looking northwards across the waters of Goodenough Bay-named by Captain Moresby after a British naval colleague, Commodore James Graham Goodenough - to the Wesleyan territory in the D'Entrecasteaux Islands, and southwards to the imposing backdrop of the Owen Stanley Range. Primitive living quarters and a chapel were built, which were precursors to eventual construction of a cathedral. The setting had a romanticism that evidently appealed to the Anglicans and to the images of famous cathedral settings in England (Wetherell 1977).

The Anglicans at Dogura were, overall, High Church or Anglo-Catholic in preference, although Reverend King himself classified as Low Church. They adopted Roman Catholic traditions, giving emphasis to the dogmatic and sacramental aspects of Christianity on the continuity of the church from the Middle Ages and in its sympathy with other churches of Catholic Christendom - that is, Tractarianism (Langmore 1989, 320). The confessional was used, and some priests were celibate. There were impressive colourful vestments for ceremonial and other occasions, and 
an acceptance of episcopal authority. They preferred the full rituals of worship including the use of incense and, most importantly, participation in the holy eucharist and its common association with the controversial doctrine of a magical transubstantiation, whereby the bread and wine of the eucharist changes to the actual body and blood of Jesus Christ. These rituals differed from the less visual theatre of the chapel services preferred by the nearby, less mystical, Wesleyan Methodists on Dobu Island. The Wesleyans, nevertheless, could influence powerfully and emotionally in the best evangelical tradition, by preaching on both the forgiveness of God and the mythical terrors of the Devil—damnation and the punishment of Hell for unrepentant sinners. Missionaries as a whole tended to be strict and dominant towards the Papuans, as they wished to impose Christianity on their poor brethren, but some also wished to escape the confines of their own European culture and so were empathetic towards the Papuans. This 'dominance' versus 'escapism' tension was experienced by other Anglo-Catholic missionaries in south-eastern Papua (Garland 2000).

Dogura is at the south-eastern extreme of its appointed Anglican territory and not too far by boat eastwards round East Cape to the harbour at Samarai and to their counterparts of the LMS Kwaito Mission in the Milne Bay area. Dogura is also, however, more than 320 kilometres in a direct line to the mouth of the Mambare River and is much further by sea after taking navigational detours past the headlands of Cape Vogel and Cape Nelson. The immediate presence of pacifying missionaries in the troubled conflict zone between the Binandere warriors and gold prospectors up the Mambare River would have been advantageous to the administration, but the Dogura missionaries were unable to provide immediate help for several more years yet.

The influence of the Anglicans along the coast to the west was slow because of inadequate staff numbers and weak funding support from their mother church in England. They did not use Polynesians as 'advance-guard' missionaries in the same way as the LMS and Methodists (Wetherell 1977, 98), but rather gave an early preference for local Papuans becoming trained as teachers, pastors and priests. Coastal mission stations, however, gradually became established, including at Wanigela at the foot of Mount Victory and at Sefoa near Tufi on Cape Nelson. Reverend King himself eventually, in 1900, transferred to a dangerous mission station, Mamba, in the Mambare River area. He there learnt and documented the Binandere language as a means of attempting to evangelise through words and ceremony the warring Orokaiva in those distant parts of the Anglican's appointed territory. 

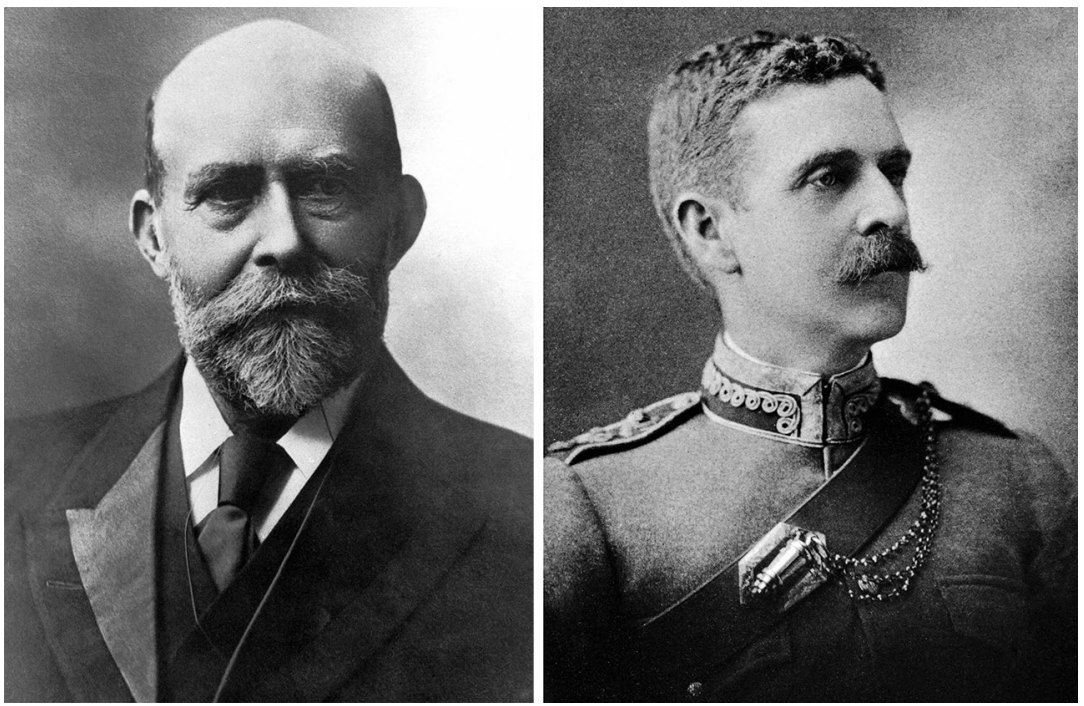

Figure 1.4. Portrait photographs of Sir William MacGregor (left) and Lord Lamington (right) in 1899

The Second Baron Lamington served as governor of Queensland from 9 April 1896 to 19 December 1901 (Joyce 1983). His full name was Charles Wallace Alexander Napier Cochrane-Baillie. Both digital images are reproduced here courtesy of the State Library of Queensland, Brisbane.

Reverend Montagu John Stone-Wigg became the first Anglican bishop of New Guinea in 1898, the year that MacGregor left British New Guinea. MacGregor, at the end of his term of office, and in assessing the effectiveness of the four different missions, declared publicly that the Wesleyan Methodists 'have fully maintained without flagging the zeal and industry with which they began, with the result that there is perhaps no more successful mission than theirs [in British New Guinea]' (MacGregor 1898a, xxx). The Anglicans evidently did not fit this same description, and MacGregor seemingly would have liked some Wesleyan-like assertiveness and energy in penetrating new fields that required pacification. Here, then, was a challenge for the inaugural Anglican bishop. Stone-Wigg was the son of an English gentleman, educated at Winchester private school and then at Oxford University. He arrived in Australia at Brisbane in 1891 and served as bishop in New Guinea until 1908. He was able to assist in enhancing the effectiveness of the Anglican mission, in part because of influence from his being so well connected with the higher echelons of society in Australia. 
Stone-Wigg, on his first episcopal visit to New Guinea, was in the company of both Lord Lamington, the governor of Queensland, and Sir Hugh Nelson, the Queensland premier. This visit coincided with Sir William MacGregor's last official tour of duty in 1898, and the four travelled around the coast of the possession together in the Merrie England (MacGregor 1898b; Wetherell 1977). 'Lamington' thereafter starts to appear as a name in reports and on maps for the mountain west of the Hydrographers Range, but it was not recognised yet as a volcano.

\section{Eruption at Mount Victory (1880s-90)}

William MacGregor was on the Merrie England in 1890 on one of his earlier voyages to the north-eastern coast of south-eastern New Guinea when he recognised that Mount Victory on the Cape Nelson peninsula was an active volcano (MacGregor 1890). He was not, however, the first European to do so, as Reverend James Chalmers and others on board the Governor Blackall on 24 October 1885 observed, and Chalmers later noted briefly, that the mountain-it was wrongly called 'Mount Nelson'—was:

Very distinct, and had all the appearance of a crater on its east side, and certainly there were more on board in favour of its being a living volcano than against it. Heavy clouds hung over the top, and at various places long jets of steam appeared to rise. (Chalmers 1887, 102)

Five years later, in late July 1890, Mount Victory seems to have had a different appearance, as MacGregor wrote that the mountain had 'great masses of bare rock' near its summit. Further:

Its sides were scored and marked by brown lines from near the summit to its base; these at first looked as if caused by lava running down the mountain, but the closest inspection could detect no presence of lava, so that it was concluded that these lines had been caused by recent great earthslips ... a few days later we had the opportunity in the early morning of seeing numerous columns of steam rising, some from the very tops of the of the two crests of Mount Victory ... [where] vegetation is very scant ... Flame was not at any time seen by us on Mount Victory, nor could we obtain from the natives any information regarding it. (MacGregor 1890, 14) 
MacGregor and others saw the volcano again in following years (MacGregor 1893, 1894; see also Moreton 1894). These included Queensland geologist A.G. Maitland (1892a, 1892b) who, in May-October 1891, travelled with the administrator on the Merrie England along the coast to the D'Entrecasteaux Islands, but not past Collingwood Bay, beyond which he might have observed volcanoes other than Mount Victory.

The effects of the eruption at Victory were substantial. Reverend Arthur K. Chignell at Wanigela Mission in 1909 wrote:

It is not every man who can boast of an active volcano in his backyard, but there it is ... always with white steam, or spirals of darker smoke ascending from a dozen fissures in its rugged crown. The elder men in Wanigera [Wanigela] will tell you of a time when the 'burning mountain' burst asunder, and sent flaming streams of lava flowing down to the sea, and they remember how the people dwelling on the higher ground made haste to build new and safer homes more near the shore, and how from that time onwards travellers and huntsmen have been careful to keep away from the slopes of Keroro [Victory]. (Chignell 1911, 1-2)

Dr W.M. Strong was a medical officer and a resident magistrate along the north-eastern coast between 1908 and 1912, and he told a similar story to Chignell's about the still active volcano and its recent eruption:

I visited the upper slopes of it in 1911, and could quite clearly see steam rising from vents at the top. Reliable native accounts show that some forty years ago there was an extensive eruption-one or more villages were overwhelmed —and the Awanabairia people, who then lived on its slopes, fled to their present home at Lakwa. (Strong 1916, 409)

There is also reference to the disastrous eruption through much later anthropological studies of the Miniafia people (Wakefield 1989). The Miniafia had lived in the Cape Nelson area on Collingwood Bay but some of them survived the eruption and escaped, taking up unoccupied land at the base of Cape Vogel peninsula to the east. One group or phratry, the Asabuworoto, although demoralised and disorganised, was able to maintain their identity as a social unit even though, importantly, those who knew their 'origin story' had been killed in the eruption. 
Little else is known about the eruption at Mount Victory, but the above quotations are sufficient evidence for a conclusion that the outbreak was an explosive, ash-producing one of substantial size and impact. No literate observers, however, are known to have witnessed and recorded the eruption, or indeed any explosive eruptions following it. Even the year of the Victory eruption is uncertain. Earlier voyagers, such as Moresby in 1874, Chalmers in 1885 and Finsch in 1884-85 (Moresby 1876; Chalmers 1887; Finsch 1888), do not refer to the devastation recorded by MacGregor, so possibly the eruption took place in the late 1880 s or even in early 1890 (e.g. Horne 1974b). The duration of the eruption-whether days, weeks or months - is also unknown. The 'brown scores', 'earthslips' and 'flaming streams' may refer mainly to hot pyroclastic flows or nuées ardentes. This well-known volcanological term was first introduced to science by a French volcanologist following the devastating eruption at Mont Pelée that destroyed the town of St Pierre on Martinique Island in the Caribbean in May 1902 (Lacroix 1904). This type of explosive eruptive activity came to be called peléean, a term that would be used internationally for several decades afterwards, including, notably, for the disastrous eruption at Mount Lamington on 21 January 1951. Victory and Lamington volcanoes, therefore, may have been built by similar kinds of eruptions.

Coastal Orokaiva living on and near the western side of the Cape Nelson peninsula would have seen the eruption from Mount Victory and would have suffered from it where ash fallout affected their gardens and fishing grounds. The extent to which the eruption was also observed in other more distant and mountainous parts of Orokaiva country 100 or so kilometres to the north-west is also unknown. The eruption cloud, however, could have been seen from what became known as Mount Lamington if it was high and persistent enough, and if visibility was unaffected by long periods of poor weather. Falls of volcanic ash in the Lamington area are not out of the question either. There is, therefore, the possibility that these mountain Orokaiva may have known from this volcanic experience what a 'volcano' and an 'eruption' were in practice, although not necessarily in name. 


\section{Between the Eras (1898-1907)}

The year 1898 marked the end of MacGregor's historically memorable, decade-long rule, but British administration of New Guinea continued for several more years. The two subsequent British New Guinea administrators were the lesser-known Sir George Le Hunte in 1898-1903 and then Captain Francis Rickman Barton in 1904-07, and there were even lesser-known acting administrators between these main periods of government service. In 1907 Barton handed over the role of acting administrator to an Australian, John Hubert Plunkett Murray, who began a notable and sustained period of rule as administrator or 'Australian pro-consul', lasting 32 years (West 1968; Nelson 1986).

Conflict and bloodletting between the Orokaiva on the one hand and the foreign gold miners and administration officers on the other had not ceased by the first year of the new century. There was still trouble on the northern rivers in 1900 where the extent of the auriferous ground was known now by the miners-mainly in the headwaters and tributaries of the Mambare, including the valley hosting the Yodda Goldfield, and further north-west in the Gira River, the Gira Goldfield (Nelson 1976).

In early 1900, the resident magistrate for the Northern Division, Belgiumborn W.E. Armit, undertook the first government patrol from Tamata on the Mambare to the upper Yodda. He constructed a road and killed many Orokaiva while doing so, characterising the Binandere attackers as 'treacherous, truculent, aggressive, cruel, and cunning ... and [they] lie abominably ... It will be necessary to teach these tribes a salutary lesson' (Armit 1900a, 98). Armit's comments about the patrol and the killings are recorded historically in his official reports. They were received with 'great uneasiness' by Administrator Le Hunte who asked Armit for more details and a fuller explanation (Le Hunte 1900, 92). Armit, in reply, was largely unrepentant and stated that he and his police had killed 54 Orokaiva over a period of a month, including two women who were carrying 'spare spears for their husbands' (Armit 1900b, 93). Reverend Lawes called Armit 'a shooter of blacks' (Wetherell 1977, 35; see also Nelson 1976, for further information on Armit). 
Reference is made to Mount Lamington and to the agricultural value of its slopes in the administration's annual report for 1904-05: 'the soil is of volcanic origin ... and is uniformly good thus giving an area ... of the finest agricultural land ... This land is perfectly situated for the culture of cocoa (cacao)' (Administrator 1904-05, 4). This information evidently came from C.A.W. Monckton, the resident magistrate of the Northern Division at the time. Monckton, a New Zealander, first became a resident magistrate in 1897 under MacGregor's rule (e.g. Lutton 1978). Monckton admired MacGregor and seems to have been rather similar in some ways to the administrator: energetic; intelligent; adventurous; a willing explorer of new, difficult country; and not averse to using force and firepower to quell Papuans judged to be difficult and non-conforming. Monckton's years of official service as a resident magistrate included long periods in both the Northern and North-Eastern divisions. The square-jawed and heavily moustachioed Monckton later showed himself to be an engaging writer and literary raconteur by publishing two successful books in Britain in the early 1920s (Monckton 1921, 1922) and another in 1934.

Monckton advocated, quite openly, a 'shoot-and-loot' approach to the colonial domination of Papuan groups who continued to fight among themselves (Monckton 1921, 208). He was, however, highly supportive of the Papuan armed constabularies who served both him and the administration's interest in tribal pacification. The constables in turn provided Monckton with a loyalty reminiscent of a Roman 'Pretorian guard', although the full extent to which the police themselves used Monckton for their own purposes is still not entirely clear (Nelson 1976). Monckton also recruited Orokaiva warriors, especially the fierce Binandere whom he judged as having the qualities needed for such police work.

In 1903, the acting administrator, Anthony Musgrave, instructed Monckton to explore the possibility of establishing a road-a new supply route- between the coast at Oro Bay and the inland goldfields by surveying the northern and north-western slopes of Mount Lamington. Monckton, who would be accompanied by a government surveyor, referred to the challenge as the 'Lamington expedition'. He warned the surveyor, Mr Tooth, about the difficulties ahead: 'You can't make an omelette without breaking eggs, and you can't take an expedition past Mt Lamington without some one being killed on one side or the other' (Monckton 1921, 297). Monckton had had previous experiences with the local peoples of the Lamington area; he had used the constabulary force to intervene in a bloody conflict between the Dobudura and the Notu peoples, a general conflict that also involved the nearby warring Sangara. 
Monckton participated in an even more challenging expedition in 1903. This one was instigated by Acting Administrator Judge C.S. Robinson and, like the Lamington expedition, the aim was to discover better access between the coast and the goldfields in the north-west interior (Monckton 1905, 1921). The Robinson-Monckton party, including police, travelled from Porloch Bay on the south-eastern edge of Dyke Acland Bay westwards and inland, south of the Hydrographers Range and then south of Lamington, managing to reach the government station of Papaki in the goldfields. However, this was arduous country. No road could be built south of Mount Lamington and, instead, the Yodda Road or, more realistically, the Yodda 'track', was constructed in 1904 under Monckton's direction to the north of the mountain. The road had to be built well north of the upper slopes of Mount Lamington to avoid as much as possible the numerous gullies and creeks that cut into the northern piedmont area of the mountain. Further, the road had to cross the wide Kumusi River at Wairopi, also spelt Wairope ('wire rope'), the name emerging after construction was completed of a metal hawser and a travelling block for loads. Mount Lamington evidently was not recognised yet as a volcano.

Judge Robinson was impressed by the energetic work of the resident magistrate on his 1903 expedition, and indeed by Monckton's martial abilities in general. However, in the same year, Monckton was suspected of responsibility for the 'Paiwa massacre' in which the resident magistrate's loyal Binandere-sourced policemen bayoneted recalcitrant Paiwa people to death in hand-to-hand fighting, an action supported in principle by Judge Robinson (e.g. Wetherell 1977). The acting administrator even named a prominent peak in the Owen Stanley Range in honour of his resident magistrate. Mount Monckton is more than twice the height of the mountain named after Lord Lamington, and is only 30 kilometres south-west of it, on the other side of the Kumusi River (see, for example, Figure 2.2).

A final achievement of the British administration was accomplished, also in 1904, when a government station was completed at Kokoda in the northern foothills of the Owen Stanley Range. The station was built on a small plateau directly west and in full view of Mount Lamington, overlooking the Yodda Valley and its alluvial gold diggings to the northwest. The station, in picturesque mountainous country, was a showpiece of the Papuan field service (e.g. Murray 1912; Nelson 1976). The Yodda Road thus became an important communication link from the coast not 
only to the Yodda Goldfield but also for Kokoda. According to Monckton $(1934,41)$, the road was 'a sanctuary for any and everyone; the wildest tribes only visit it in peace to trade food and goods to passing travellers'. Even Hubert Murray, who was not an admirer of Monckton, wrote later:

The Wasida and Sangara have been particularly active in forming markets along the road which leads from Buna Bay to the Yodda Goldfield, and in supplying carriers with taro and other food in exchange for articles of trade, such as tobacco, and glass bottles, which are much prized for the manufacture of razors. (Murray 1912, 105)

The importance of a road from the coast to Kokoda and Yodda would be demonstrated clearly in later times when major historical events demanded its use both as a military route and as a disaster relief lifeline. The Yodda Road arguably can be regarded as the most significant historical legacy of Monckton, the 'reprobate magistrate' (Lutton 1978, 48), and of surveyor Tooth. 
This text is taken from Roars from the Mountain: Colonial Management of the 1951 Volcanic Disaster at Mount Lamington, by R. Wally Johnson, published 2020 by ANU Press, The Australian National University,

Canberra, Australia.

doi.org/10.22459/RM.2020.01 